\title{
Category of nutritional status of adolescents according to sex and the place of residence
}

\author{
Irzada Taljić1 ${ }^{*}$, Almir Toroman ${ }^{2}$ \\ ${ }^{1}$ University of Sarajevo, Faculty of \\ Educational Sciences, Skenderija 72, 71000 \\ Sarajevo, Bosnia and Herzegovina \\ 2University of Sarajevo, Faculty of \\ Agriculture and Food Sciences, Zmaja \\ od Bosne 8, 71000 Sarajevo, Bosnia and \\ Herzegovina \\ Received: $20^{\text {th }}$ September 2016
}

Corresponding author:

E-mail address (of the presenting/corresponding author): hirzada@hotmail.com

\begin{abstract}
World-wide organizations focus research to the infancy and early childhood development because adolescence is not considered vulnerable as previous two stages. But it is very complicated period of life (physical and cognitive growth and development) with high impact of risky behaviour and the deadlines for establishment of good practices including food habits. The study included 630 participants, 133 adolescents from the rural part (60 boys and 73 girls) and 497 adolescents from urban part (264 boys and 233 girls) of Canton Sarajevo. Participants were 13-15 years old. Anthropometric measurements were used: measurement of body weight and body height in order to calculate the BMI-for-age percentiles and skinfold thickness at four sites (biceps, triceps, subscapula, stomach) as additional parameters for determining category of nutritional status. Data were statistically analyzed using SPSS 13.0. Results show no statistical significance of the place of residence in relation to any tested parameter among girls. While among boys statistical significance was demonstrated in relation to the differences in the mean skin fold of subscapula $(U=6138.5, p=0.02)$, stomach ( $U$ $=5847.5, p=0.005)$, biceps $(U=6297.5, p=0.038)$, triceps $(U$ $=6161.5, p=0.022)$, and mean values of measured four skinfolds $(U=7661.5, p=0.007)$ where boys from rural areas have lower levels of skinfolds and lower mean of all four measured skinfolds. Results of BMI-for-age percentiles according to sex and the place of residence, show that normal weight is prevalent among adolescents in the Canton Sarajevo followed by overweight and obesity. Results indicate that adolescents in the urban part of Canton Sarajevo are thicker, there is higher number of overweight adolescents and among them is a higher percentage of adolescent girls.
\end{abstract}

Keywords: adolescents, place of residence, BMI-for-age, skinfold thickness.

\section{INTRODUCTION}

World-wide organizations focus research to the infancy and early childhood development because adolescence is not considered vulnerable as previous two stages. But it is very complicated period of life (physical and cognitive growth and development) with high impact of risky behaviour. During adolescence $50 \%$ of the total weight is gained and more than $20 \%$ of height (1). Many of the habits acquired in adolescence last a lifetime. Adolescents are particularly challenging age group because they require a complex approach, both because of their relation to health or due to the impact of their current attitudes, habits and behaviors to health in the future. Also, health problems related to nutrition and acquired at a young age, can be corrected during adolescence. The overall nutritional status is best manifested by anthropometry in adolescents, as well as in other life cycles. Taking into account essential facts relating to the composition of the body during adolescence, assessment of obesity and malnutrition is more complicated in adolescents than in adults or children (2). Nutritional status of children and adolescents depends on gender and age and is expressed by BMI-for-age percentiles or z-score. There was necessity for appropriate reference growth monitoring, supervision and control of school children and adolescents, and WHO expert group has made a growth curve for that population, which is consistent with the WHO Child Growth Standards for preschool children and BMI limits for adults. They used a combination of data from 1977 of the National Center for Statistics in Health (NCHS) and WHO growth reference (124 years old) with data from Standard growth in children 18-71 months of age to make transition between samples smooth. New curves correspond to the WHO Child Growth Standards for children under 5 years of age and recommended limit values of overweight and obesity up to 19 years of age. They fill the gap and provide a suitable reference for a group of 5-19 years of age (3). BMI is dependent on the sex and age of children and young people and absolute BMI of children and young people is not a good parameter for the classification of overweight and obesity. The percentage of fat changes with age and is different in girls and boys. Therefore, the relative BMI or use of percentiles depended on age and sex is better (4). This means that children 
whose BMI-for-age is between $90^{\text {th }}-97^{\text {th }}$ percentile are overweight. If the BMI-for-age is above the $97^{\text {th }}$ percentile its' childs' or juvenile obesity.

\section{OBJECTIVE}

Because of the lack of data and the importance of maintenaning optimal weight status during adolescence, objective of this research was evaluation of nutritional category of adolescents according to gender and type of settlement (urban or rural) in Canton Sarajevo, Bosnia and Herzegovina.

\section{SUBJECTS AND METHODS}

Subjects: The study included 630 participants, 133 adolescents from the rural part ( 60 boys and 73 girls) and 497 adolescents from urban part (264 boys and 233 girls) of Canton Sarajevo. Participants were 13-15 years old. Distribution of participants is accordant to the demographic data of the Federal Bureau of Statistics of the Canton Sarajevo (5).

Settlement: Research has been conducted in Canton Sarajevo. Since, Urbanistic Studies of the Sarajevo Canton are in its' development, division of Canton Sarajevo by the type of settlement (urban and rural area) has been done according to the Spatial Plan of the Sarajevo Canton for the period 2003- 2023 (6).

Methods: Anthropometric measurements included: measurements of body weight and body height; measurements of skinfold thickness at four sites (biceps- $m$. biceps brachi, triceps$m$. triceps brachi, subscapula- subscapula, stomach- umbilicus) and calculation of BMI-for-age percentiles. Anthropometric measurements were conducted according to current methodology $(7,8)$. Data were statistically analyzed using SPSS 13.0.

\section{RESULTS}

BMI categories are presented in graph 1 and skinfold thickness in tables 1 and 2 .

Graph 1 shows that normal weight is prevalent among adolescents in the Sarajevo Canton: $70.00 \%$ of boys from rural area is in a normal weight category as well as $58.33 \%$ of boys from urban area. $65.75 \%$ of girls from rural area as well as $54.98 \%$ in rural area are among normal weight category. Overweight follows normal weight: $20.00 \%$ of boys in rural areas are overweight as well as $24.24 \%$ in the urban area. There is $19.18 \%$ of overweight girls in rural area and $25.54 \%$ in urban area. Obesity is present among $10.00 \%$ of boys in rural and $14.39 \%$ of boys in an urban area and among $15.07 \%$ of girls in rural and $16.88 \%$ of girls in the urban part of Sarajevo Canton. Underweight category is not present among adolescents in rural part of Canton Sarajevo. It is present among $3.0 \%$ of boys and $2.60 \%$ of girls in urban part. Man Whitney test (U) showed that differences in the mean BMI-for-age among adolescent girls from urban and rural areas are not statistically significant $(U=7883.0, p=$ $0.402)$. BMI of rural girls, BMIr $=20.56(18.53-$ 23.13 ) is slightly lower than the BMI of urban girls, BMIu = $21.24(18.93$ - 23.77) but this difference was not statistically significant. Man Whitney test showed that differences in the mean BMI-for-age among adolescent boys in urban and rural areas are not statistically significant $(U=7111.5, p=$ $0.438)$. BMI-for-age of rural boys is BMIr $=20.25$ (18.33 - 22.36) and is slightly lower than the BMIfor-age of adolescents in urban areas, BMIu =

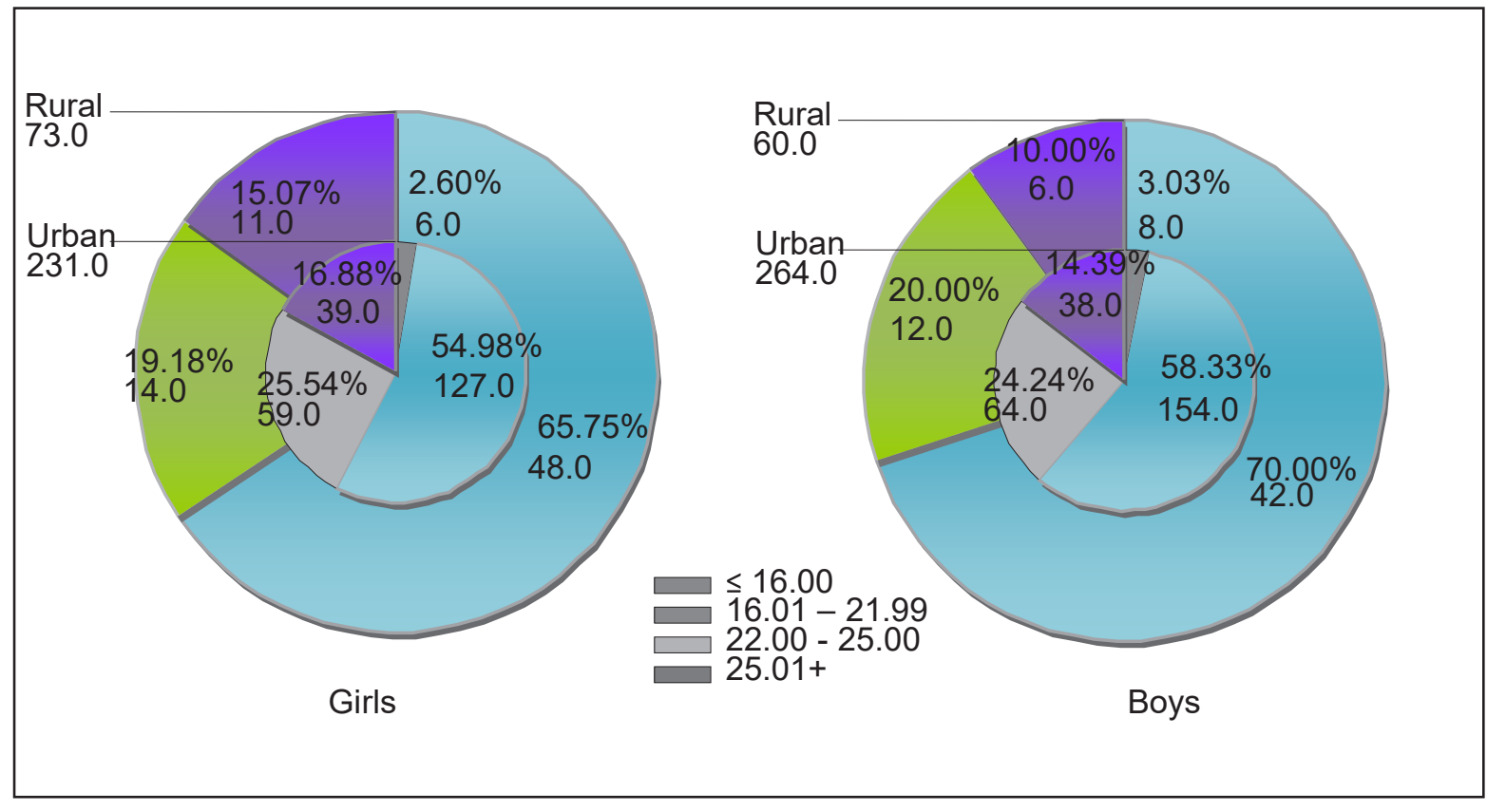

Graph 1. BMI categories of adolescents by gender and by the type of settlement 
20.78 (18.49 - 23.38), but this difference was not statistically significant.

There is no statistical significance of any of measured four skinfold thickness in girls in relation to type of settlement but thickness of three skinfolds: subscapula, biceps, triceps and mean four skinfolds is higher in urban adolescents (rural vs urbano: subscapula: $13.00(11.00-17.50) \mathrm{mm}$ vs $14.00 \mathrm{~mm}$ (11.00 - 19.00)mm; stomach: 20.00 $(15.00$ - 26.00)mm vs $19.00 \mathrm{~mm}(14.00$ - 25.00) $\mathrm{mm}$; biceps: 15.00 (12.00 - 20.00)mm vs 16.00 $\mathrm{mm}(12.50$ - 20.00)mm; triceps: 18.00 (15.00 $24.00) \mathrm{mm} 20.00 \mathrm{~mm}(15.00-25.00) \mathrm{mm}$; mean of four skinfolds: 16.75 (13.75 - 20.63)mm vs 18.25 $\mathrm{mm}(14.00-21.63) \mathrm{mm})$.

Man Whitney test showed that the differences in the mean values of skinfolds: subscapula ( $U$ $=6138.5, p=0.02)$, stomach $(U=5847.5, p=$ $0.005)$, biceps $(U=6297.5, p=0.038)$, triceps $(U=6161.5, p=0.022)$ and the mean value of the four skinfolds $(U=7661.5, p=0.007)$ among adolescent boys in urban and rural areas are statistically significant. Where adolescents from rural areas have lower values of skinfolds and lower the mean of all four measured skinfolds (rural vs urbano: subscapula: $10.00(8.00$ - 12.00)mm vs $10.00 \mathrm{~mm}(9.00$ - 15.00$) \mathrm{mm}$; stomach: 11.00 (9.00-18.00)mm vs $14.00 \mathrm{~mm}(11.00$ - 22.00) mm; biceps: 9.00 (6.00 - 14.00)mm vs 11.00 ( 8.00 - 15.25)mm; triceps: 12.00 (10.00 - 16.00) $\mathrm{mm}$ vs $14.50(11.00$ - 20.00)mm; mean of four skinfolds: $10.25(8,25$ - 15.00)mm vs 12.50 (9.75 - 18.25)mm).

\section{DISCUSSION}

There are mixed and conflicting evidences about the differences of children and adolescents from rural and urban areas. According to one study (9) of the total number of children in urban areas $44.0 \%$ are classified as overweight or at risk of overweight $(20.0 \%$ overweight; $24.0 \%$ in the risk of overweight), and the remaining $56.0 \%$ had a BMI below $85^{\text {th }}$ percentile. In a sample of children from rural areas $42.8 \%$ was considered overweight or at

Table 1 . Skinfolds of girls by type of settlement

\begin{tabular}{|c|c|c|c|c|c|c|c|c|c|c|c|}
\hline \multirow[b]{2}{*}{$\begin{array}{l}\text { Type of } \\
\text { settlement }\end{array}$} & \multirow[b]{2}{*}{ Skinfolds $\mathbf{N}$} & \multirow{2}{*}{\multicolumn{2}{|c|}{${ }^{-} x$}} & \multirow[b]{2}{*}{$\sigma M$} & \multirow[b]{2}{*}{ in $\mathbf{M}$} & \multirow[b]{2}{*}{ ax 2} & \multicolumn{3}{|c|}{ Percentiles } & & \multirow[b]{2}{*}{$p$} \\
\hline & & & & & & & $5^{\text {th }} 5$ & $\begin{array}{c}0^{\text {th }} \\
\text { Median }\end{array}$ & $75^{\text {th }} \mathrm{U}$ & & \\
\hline Rural & & 731 & 4.675 & .70 & 8.003 & 3.001 & 1.001 & 3.001 & 7.50 & & \\
\hline Urban & Subscapula & 225 & 16.02 & 6.536 & .00 & 40.00 & 11.00 & 14.00 & 19.00 & 7164.0 & 0.101 \\
\hline Rural & & 732 & 1.459 & .25 & 8.005 & 5.001 & 5.002 & 0.002 & 6.00 & & \\
\hline Urban & Stomach & 225 & 20.35 & 7.864 & .00 & 48.00 & 14.00 & 19.00 & 25.00 & 7871.0 & 0.563 \\
\hline Rural & & 731 & 5.456 & .01 & 4.003 & 6.001 & 2.001 & 5.002 & 0.00 & & \\
\hline Urban & Biceps & 225 & 16.52 & 5.555 & .00 & 32.00 & 12.50 & 16.00 & 20.00 & 7180.0 & 0.106 \\
\hline Rural & & 731 & 9.146 & .63 & 8.004 & 0.001 & 5.001 & 8.002 & 4.00 & & \\
\hline Urban & Triceps & 225 & 20.56 & 6.387 & .00 & 35.00 & 15.00 & 20.00 & 25.00 & 7104.0 & 0.083 \\
\hline Rural & & 731 & 7.685 & .85 & 7.253 & 5.751 & 3.751 & 6.752 & 0.63 & & \\
\hline Urban & Mean & 225 & 18.36 & 5.586 & .25 & 34.00 & 14.00 & 18.25 & 21.63 & 7571.0 & 0.316 \\
\hline
\end{tabular}

Table 2. Skinfolds of boys by type of settlement

\begin{tabular}{|c|c|c|c|c|c|c|c|c|c|c|c|}
\hline \multirow[b]{2}{*}{$\begin{array}{l}\text { Type of } \\
\text { settlement }\end{array}$} & \multirow[b]{2}{*}{ Skinfolds } & \multirow[b]{2}{*}{$\mathbf{N}$} & \multirow[b]{2}{*}{${ }^{-} x$} & \multirow[b]{2}{*}{$\sigma$} & \multicolumn{5}{|c|}{ Percentiles } & \multirow[b]{2}{*}{$\mathbf{U}$} & \multirow[b]{2}{*}{$p$} \\
\hline & & & & & Min & Max & $25^{\text {th }}$ & $\begin{array}{l}50^{\text {th }} \\
\text { Median }\end{array}$ & $75^{\text {th }}$ & & \\
\hline Rural & & 591 & 1.245 & .25 & 6.003 & 0.008 & .00 & 10.00 & 12.00 & & \\
\hline Urban & Subscapula & 2581 & 3.136 & .56 & 5.004 & 0.009 & .00 & 10.00 & 15.00 & 6138.5 & 0.02 \\
\hline Rural & & 591 & 4.588 & .60 & 6.004 & 3.009 & .00 & 11.00 & 18.00 & & \\
\hline Urban & Stomach & 2581 & 7.219 & .03 & 6.005 & 3.001 & 1.001 & 4.002 & 2.00 & 5847.5 & 0.005 \\
\hline Rural & & 591 & 0.395 & .18 & 4.002 & 4.006 & .00 & 9.001 & 4.00 & & \\
\hline Urban & Biceps & 2581 & 2.286 & .26 & 3.003 & 5.008 & .00 & 11.00 & 15.25 & 6297.5 & 0.038 \\
\hline Rural & & 591 & 3.465 & .13 & 6.002 & 7.001 & 0.001 & 2.001 & 6.00 & & \\
\hline Urban & Triceps & 2581 & 5.816 & .83 & 5.003 & 6.001 & 1.001 & 4.502 & 0.00 & 6161.5 & 0.022 \\
\hline Rural & & 591 & 2.415 & .62 & 5.752 & 7.258 & .25 & 10.25 & 15.00 & & \\
\hline Urban & Mean & 2581 & 4.616 & .54 & 5.253 & 6.009 & .75 & 12.50 & 18.25 & 7661.5 & 0.007 \\
\hline
\end{tabular}


risk of overweight ( $25.7 \%$ and $17.1 \%$ respectively), while the remaining $57.1 \%$ had a BMI below the $85^{\text {th }}$ percentile. The differences between urban and rural samples in terms of percentage in each BMI category was not statistically significant $(N=135$, $\mathrm{X} 2=0.949, p=0.622$ ). other study (10) examined differences in adolescents in urban and rural part of Italy, Pistoia, Tuscany, and the results showed that BMI was significantly higher in children from rural areas $(p=0.047)$, but there was no difference in the z-BMI $(p=0.072)$. The percentage of children with a BMI / 85 th percentile is higher in rural (24\%) than urban children $(18 \%)(p=0.012$, Fisher's Exact Test). Another study (11) examining the nutritional status of adolescents also in Italy (Emilia-Romagna) found that the prevalence of malnutrition among boys was quite stable ( 3.3 to $3.9 \%$ ) among $11-13$ years old, while a lower percentage was iat 14 year olds. Overweight participants were more common in the age of 11 years $(35.2 \%)$ and this share is decreasing with age $(18.7 \%$ at age 14$)$, while the percentage of obese was quite stable with age. For girls the highest percentage of malnutrition was at 13 year old, and the lowest in 14 year-old. In boys, overweight and obesity decreases with age. The prevalence of overweight and obesity is higher in boys than in girls at all age groups, except in participnats 11 year olds. Examining the nutritional status of adolescents in rural and urban areas of Cameroon (12) have proven that there is a significant difference between urban and rural adolescents by gender. BMI and overall skinfold are different although not significant. Greater proportion of urban adolescents was above the WHO reference for body weight and height. Characteristics of urban children versus rural are: years $(12.79 \pm / 0.7$ vs. $13.79 \pm 1.1)$, body weight $(45.39 \pm / 8.5$ vs $47.99 \pm / 8.1)$, body height (152.29 \pm / 9.3 vs. $152.99 \pm / 8.4)$, BMI (19.49 \pm / 2.1 vs $20.69 \pm$ / 2.3), SFT in $\mathrm{mm}(10.19 \pm /$ 4.8 vs $9.89 \pm / 3.2)$, the SFB $\mathrm{mm}(7.39 \pm / 2.5$ vs $6.39 \pm / 2.5)$, SFSS mm ( $8.89 \pm / 3.0$ vs 9.19 $\pm / 2.9)$, SFS mm (6.99 \pm / 2.5 vs $6.89 \pm / 2.4)$, total skin fold in mm (33.19 \pm / 11.6 vs $31.99 \pm$ / 9.8). While examining obesity, energy intake and physical activity in urban and rural children of New Zealand (13) got results showing that rural children had significantly lower BMI and thinner skinfolds than urban children. The differences in skinfold thickness remained after controlling the race and socio-economic status. Furthermore, the boys from urban areas had 1.3 times more likely to become overweight or obese than boys from rural areas (95\% CL 1.1-1.6, $p<0.01$ ), and girls from urban areas had 1.4 times more likely to become overweight and obese girls from rural areas (95\% CL $1.2-1.7, p<0.01)$. A cross sectional study (14) among American adolescents has shown that rural children have higher levels of obesity (16.5\%) compared to urban children $(14.3 \%)$. This is supported by the study of children aged 8-12 years from the Midwestern state in America where more rural children were overweight $(25.1 \%)$ compared to urban children (19.4\%), and urban children were less active. Furthermore, the cross sectional study of Canadian children (11-15 years) found that the degree of overweight and obesity increase with increasing 'rurality' (15). In a study designed to assess psychiatric disorders among children from rural areas, it was found that overweight and risk of being overweight is 3-4 times more prevalent in the rural sample in comparison with national standards (16). In a study of direct comparison of rural and urban children (17), found that $29.5 \%$ of rural children in their sample were overweight compared to urban, $21.7 \%$. In a study involving the children of New York found that the prevalence of the risk of overweight and obesity was $25 \%$ in a large sample of children (18).

There are two studies made in Canton Sarajevo, although, influence of residence was not examined, it is relevant to point out the available results: one study (19) found that students from fifth to eighth grade were malnourished (male vs female: $4.65 \%$ : $4.51 \%$ ), normal weight (male vs female: $37.98 \%$ : $31.82 \%$ ), overweight (male vs female: $7.49 \%$ : $5.19 \%$ ) and obese (male vs female: $3.69 \%$ : $4.31 \%$ ) and the other research was done among adolescents aged 13 to 15 years of age, showed that the largest percentage of adolescents was in the category of normal weight $(50.5 \%)$, followed by the overweight $26.3 \%$ and obese with $10.2 \%$ (20).

\section{CONCLUSION}

Results of this study, although not showing statistical significance of BMI-for-age towards gender and type of settlement, differences in the categories are small between boys and girls who grow up in different environments, however there are more adolescents with normal weight in a rural area, and obese and overweight participants in urban area of Sarajevo Canton. It is interesting that in addition to greater overweight and obesity in urban area, category of malnutrition is present in $3.00 \%$ of boys and $2.60 \%$ of girls in urban, while there is no malnutrition in rural area.

Skinfold thickness at four sites and mean skinfold of adolescent girls from rural and urban areas of Sarajevo Canton have no statistical significance, though the BMI-for-age, and skin foldsof subscapula, biceps, triceps and mean skinfolds are slightly lower in adolescent girls from rural areas. Statistical significance of type of settlement to the thickness of skinfolds at all four measured places (subscapula, stomach, biceps and triceps) and the mean of these four skinfolds was proven in boys, where adolescents from rural areas have lower values of skinfolds and a lower mean of all four measured skinfolds. 


\section{REFERENCES}

1. Spear, BA. Adolescent growth and development. J Am Dietetic Assoc 2002; 102 (Suppl), S23S29.

2. Adolescents Nutrition: A review of the situation is selected South - East Asian countries. Regional office of South East Asia. Executive Summary. WHO. 2005.

3. de Onis, M, Onyango, A, Borghi, E, Siyam, A, Nishidaa, C, Siekmanna, J Development of a WHO growth reference for school-agedchildren and adolescents, WHO. Bulletin of the World Health Organization 2007; 85: 660-667.

4. Holub, M, Gotz, M. Ursachen und Folgen von Adipsitas in Kindes und Jugendalter. Monatsschrift Kinderheilkunde 2003; 151: 227-36.

5. Popis stanovništva, domaćinstva/kućanstava i stanova u Bosni i Hercegovini 2013. Preliminarni rezultati po općinama inaseljenim mjestima u Federaciji Bosne i Hercegovine, Federalni zavod za statistiku. Statistički bilten 2007; 195/2013. Available at: www.fzs.ba, [accessed: 28.02.2014.].

6. Prostorni plan Kantona Sarajevo za period od 2003. do 2023. Zavod za planiranje razvoja Kantona Sarajevo 2006; 11, 18, 227.

7. Growth reference, BMI-for-age (5-19). WHO. 2007; Available at: http://www.who.int/ growthref/who2007 bmi for age/en/index. html [accessed: 20.04.2010.]

8. International Standards for Anthropometric Assessment. ISAK (The International Society for the Advancement of Kinanthropometry, 2001.

9. Davis, AM, Boles, RE, James, RL, Sullivan, DK, Donnelly, JE, Swirczynski, DL, Goetz, J. Health behaviors and weight status among urban and rural children. Rural Remote Health 2008; 8 (2): 810 .

10. Tognarelli, M, Picciolli, P, Vezzosi, S, Isola, A, Moretti, F, Tommassetto, E, Fantuzzi, AL, Bedogni, G. Nutritional status of 8-year-old rural and urban Italian children: a study in Pistoia, Tuscany. International Journal of Food Sciences and Nutrition 2004; 55 (5): 381-/387.

11. Toselli, S, Argnani, L, Canducci, E, Ricci, E, Gualdi-Russo, E. Food habits and nutritional status of adolescents in Emilia-Romagna, Italy. Nutricion Hospitalaria 2010; 25: 613-621.

12. Dapi, LN, Nouedoui, C, Janlert, U, Håglin, L. Adolescents' food habits and nutritional status in urban and rural areas in Cameroon, Africa. Scandinavian Journal of Nutrition 2010, 49 (4): 151-158.

13. Hodgkin, E, Hamlin, MJ, Ross, JJ, Peters, F. Obesity, energy intake and physical activity in rural and urban New Zealand children. Rural and Remote Health 2010; 10 (online): 1336. Available at: http://www.rrh.org.au [accessed: 13.04.2012.]
14. Lui, J, Bennett, KJ, Harun, N, Probst, JC. Urban-rural differences in overweight status and physical inactivity among US children aged 10-17 years. Journal of Rural Health 2008; 24 (4): 407-415.

15. Bruner, MW, Lawson, J, Pickett, W, Boyce, W, Janssen, I. Rural Canadian adolescents are more likely to be obese compared with urban adolescents. International Journal of Pediatric Obesity 2008; 3(4): 205-211.

16. Mustillo, S, Worthman, C, Erkanli, A, Keeler, G, Angold, A, Costello, EJ. Obesity and psychiatric disorder: Developmental trajectories. Pediatrics 2003; 111: 851-859.

17. McMurray, RG, Harrell, JS, Bangdiwala, SI, Deng, S. Cardiovascular disease risk factors and obesity of rural and urban elementary school children. The Journal of Rural Health 1999; 15: 365-374.

18. Thorpe, LE, List, DG, Marx, T, May, L, Helgerson, SD, Frieden, TR. Childhood Obesity in New York City elementary school students. American Journal of Public Health 2004; 94: 1496-1500.

19. Dinarević, S., Branković, S., Hasanbegović, S. Ishrana i fizička aktivnost učenika osnovnih škola u odnosu na gojaznost. Journal of Health Sciences 2011; 1(1): 46.

20. Hodžić, I., Smajić, A., Gojak, R. Risk factors influencing overweight and obesity among adolescents in Sarajevo. Proceedings of $22^{\text {nd }}$ International Scientific-Expert Conference of Agriculture and Food Industry, Sarajevo 2011; 317-318. 